\title{
THERMAL CONDITIONS RELATIVE TO ATMOSPHERIC CIRCULATION IN THE CHRISTMAS PERIOD IN POLAND
}

\author{
ARKADIUSZ M. TOMCZYK \\ Institute of Physical Geography and Environmental Planning, Adam Mickiewicz University in Poznań, Poland
}

Manuscript received: September 13, 2015

Revised version: February 3, 2016

\begin{abstract}
TомсZYк A.M., 2016. Thermal conditions relative to atmospheric circulation in the Christmas period in Poland. Quaestiones Geographicae 35(1), Bogucki Wydawnictwo Naukowe, Poznań, pp. 47-56, 8 figs.

AвSTRACT: The main objective of this article was to determine thermal conditions in the Christmas period and the impact of atmospheric circulation on their formation. The article is based on data on the mean daily air temperature for 16 stations in Poland for the 1966-2014 multiannual period. In this period, no statistically significant changes of air temperature were observed, neither in December, nor the Christmas period. The occurrence of averagely warmer holidays was associated with the inflow of maritime polar air masses from the western sector, while colder holidays occurred with the inflow of continental polar air masses from the eastern sector.
\end{abstract}

KEY WORDS: climate change, air temperature, Christmas, Poland

Corresponding author: Arkadiusz M. Tomczyk (atomczyk@amu.edu.pl)

\section{Introduction}

According to the authors of the Fifth IPCC Assessment Report (2013), the increase in global average temperature between 1880 and 2012 was $0.85^{\circ} \mathrm{C}$, and the first decade of the 21st century was the warmest since the advent of instrumental measurement. Analyses of thermal conditions in different regions of Europe have confirmed the increase in air temperature, which intensified particularly in the last decade of the 20th century and in the first decade of the 21st century (Brázdil et al. 1996, Klein Tank, Können 2003, Kürbis et al. 2009, Bardin 2011, Bartolini et al. 2012, Nordli et al. 2014). A similar trend of air temperature changes has also been confirmed in Poland, and the strongest warming has been recorded in spring and summer
(Fortuniak et al. 2001, Kożuchowski, Żmudzka 2001, Wibig, Głowicki 2002, Degirmendžić et al. 2004, Michalska 2011, Wójcik, Miętus 2014).

Atmospheric circulation is one of the basic mechanisms transferring heat in the atmosphere, and its changes, regardless of the reasons for these changes, considerably influence short-term (inter-annual and inter-decadal) air temperature variability (Marsz 2013). One important attribute of the circulation over Europe is the occurrence of high-pressure patterns, especially zonal circulation blocking patterns characterized by considerable persistence (Bielec-Bąkowska 2010). Blocking patterns in summer contribute to the occurrence of heat waves and, in winter, to the occurrence of frost waves (Porębska, Zdunek 2013).

Each year, in December, media and societal interest in the weather conditions over the 
Christmas period grows; therefore, the results presented here may turn out to be interesting to a wide and diverse group of readers. Previous research on weather conditions in the Christmas period has mainly focused on analysis of the occurrence of snow cover (Bednorz 2006, Rydén 2015).

This article aims to:

- determine air temperature changes in December between 1966 and 2014 and the impact of the North Atlantic Oscillation on thermal conditions;

- determine thermal conditions in the Christmas period, and the impact of atmospheric circulation on their formation.

\section{Data and analysis methods}

The study was based on daily data concerning the mean air temperature for 16 stations in Poland in the period of 1966-2014 (Fig. 1). The data were obtained from the records of the Institute of Meteorology and Water Management: National Research Institute. Monthly indices of the North Atlantic Oscillation were obtained from the sources of the Climate Prediction Center (the body of National Oceanic and Atmospheric Administration (NOAA)).

On the basis of the aforementioned data, the mean air temperature was calculated for

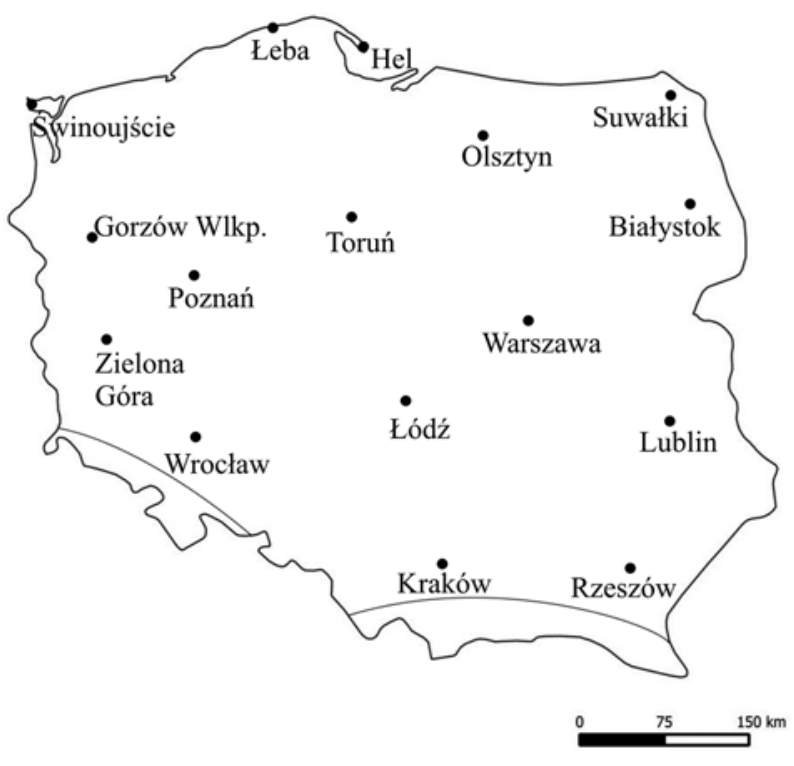

Fig. 1. Locations of the meteorological stations.
December and the Christmas period (that is December 24th to 26th). Subsequently, trends of air temperature changes in the above-mentioned period were calculated, and their statistical significance $(p \leq 0.05)$ evaluated. The next stage involved calculating the correlation coefficient between the mean air temperature in December and the monthly NAO index, and also analysing its statistical significance $(p \leq 0.05)$.

To describe the pressure conditions occurring in the Christmas period, values for daily sea level pressure (SLP) and the height of the $500 \mathrm{hPa}$ isobaric surface were used. The data were derived from the records of the National Center for Environmental Prediction/National Center for Atmospheric Research (NCEP/ NCAR) Reanalysis (Kalnay et al. 1996), which are available in the resources of the Climate Research Unit. In the study, values of SLP and $\mathrm{z} 500 \mathrm{hPa}$ in 120 geographical grid points $5^{\circ} \times 5^{\circ}$ for the area of $35^{\circ}-70^{\circ} \mathrm{N}$ latitude, $35^{\circ} \mathrm{W}-40^{\circ} \mathrm{E}$ longitude were used. The pressure conditions in the Christmas period were divided into two types. This was done by grouping Christmas seasons with regard to sea level pressure values by means of the minimum variance method known as Ward's method (1963). This method, based on Euclidean distances, in essence involves merging the pair of clusters A and B, which, after merging, will provide the minimum sum of squares of all objects' deviations from the newly-created cluster's centre of gravity (Ward 1963). Ward's method is often applied in climatology, e.g. in distinguishing climatic seasons and regions, and in identifying weather types (Birkeland and Mock 1996, Bednorz 2011). Standardised SLP values were used in the research. The standardisation was made to deseasonalise the observations, while keeping the intensity of pressure field (Esteban et al. 2005). On the basis of SLP and z500 hPa data, the mean SLP and z500 hPa in December were mapped, and maps for the distinguished types were drawn. The description was supplemented with maps of anomalies. Anomalies were defined as differences between the mean SLP and z500 hPa values for the distinguished types and the mean value of these characteristics in December in the analysed multiannual period. 


\section{Results}

\section{Thermal conditions in December between 1966 and 2014}

Between 1966 and 2014 in Poland, the mean air temperature in December was $-0.3^{\circ} \mathrm{C}$, decreasing north-easterly from the west. The lowest mean air temperature in the analysed multiannual period was recorded in Suwałki $\left(-2.4^{\circ} \mathrm{C}\right)$, while the highest were in $\operatorname{Hel}\left(1.6^{\circ} \mathrm{C}\right)$ and Świnoujście $\left(1.5^{\circ} \mathrm{C}\right)$. Among the analysed 49 years, the coldest Decembers occurred in $1969\left(-7.4^{\circ} \mathrm{C}\right)$ and in 2010 $\left(-5.3^{\circ} \mathrm{C}\right)$ (Fig. 2). In December of 1969, the mean air temperature fluctuated between $-10.3^{\circ} \mathrm{C}$ in Suwałki and $-3.6^{\circ} \mathrm{C}$ in Hel. On the other hand, the highest mean air temperature in December was recorded in $2006\left(4.3^{\circ} \mathrm{C}\right)$, and it then varied between $2.4^{\circ} \mathrm{C}$ in Kraków and $6.2^{\circ} \mathrm{C}$ in Łeba and $6.3^{\circ} \mathrm{C}$ in Hel. The course of mean air temperature in winter shows considerable year-to-year fluctuations; however, that changeability was similar within the investigated area, as was proven by the low diversity of standard deviation values, ranging from 2.0 to $2.9^{\circ} \mathrm{C}$, while in $70 \%$ of stations they lie within the $2.0-2.5^{\circ} \mathrm{C}$ range. In the analysed multiannual period, there was an increase in air temperature observed, which fluctuated from

Kraków

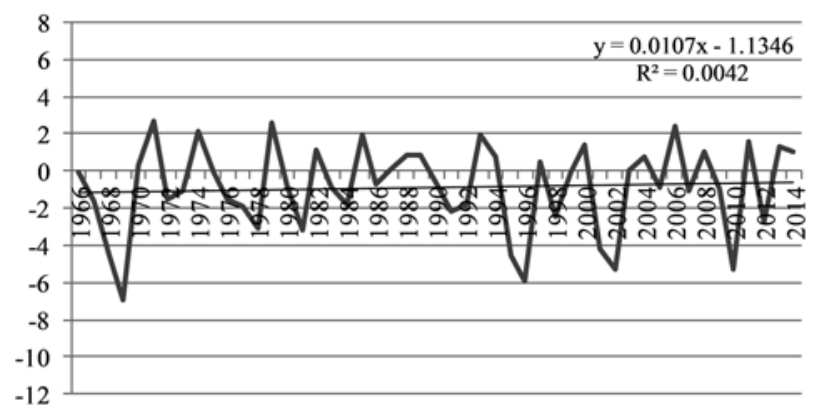

Suwałki

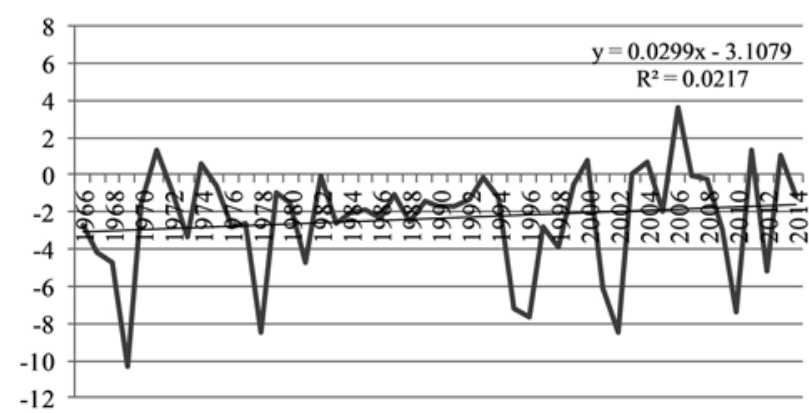

$0.09^{\circ} \mathrm{C} / 10$ years in Lublin to $0.30^{\circ} \mathrm{C} / 10$ years in Suwałki; however, these changes were not statistically significant.

Throughout the month, air temperature gradually decreases; on average, the warmest was the first decade of December. The Christmas period was associated with a several-day warming, which usually occurred between the 22th or 23rd December and 26th or 27th December (Fig. 3). The aforementioned warming was preceded by a several-day colder period occurring between the second and third decades of the month. After the warmer period, there was a gradual decrease in air temperature at Christmas time.

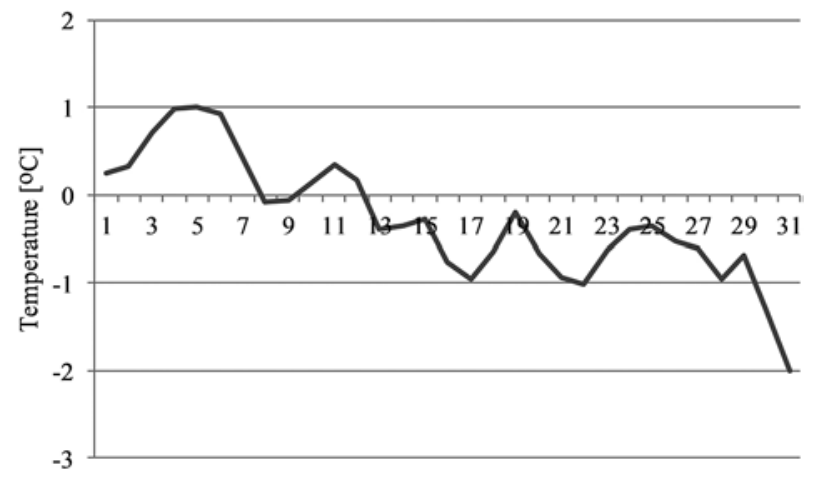

Fig. 3. Mean daily air temperature $\left({ }^{\circ} \mathrm{C}\right)$ in December between 1966 and 2014 in Poland.

Leba

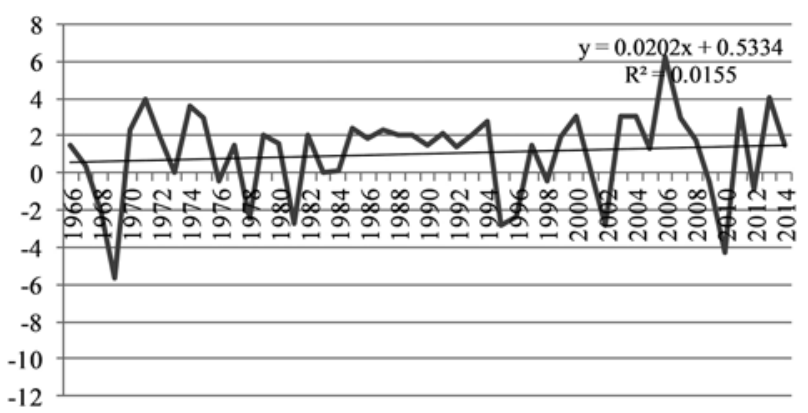

Świnoujście

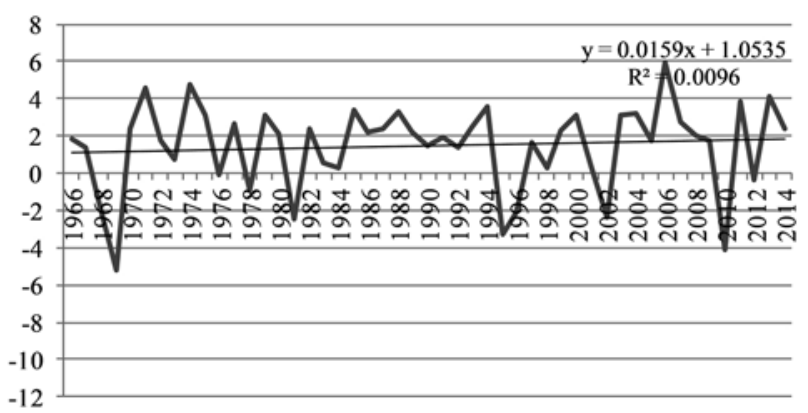

Fig. 2. Mean air temperature $\left({ }^{\circ} \mathrm{C}\right)$ in December between 1966 and 2014 in selected stations. 
The impact of the North Atlantic Oscillation on air temperature in December

The North Atlantic Oscillation is a bipolar type of circulation resulting from interaction between the Azores High and the Icelandic Low. The occurrence of a low value of atmospheric pressure in the centre of the Icelandic Low synchronically with considerable high pressure in the Azores High is defined as the positive stage of NAO. On the other hand, the co-occurrence of higher-thanmean pressure in the Icelandic Low and lower-than-mean pressure in the Azores High constitutes the negative stage of NAO. During the positive stage of NAO, a great pressure gradient occurs between the above-mentioned pressure centres, causing an inflow of air from the west and transport of humid and warm air masses over the northern part of the continent. On the other hand, a negative NAO index is associated with an inflow of dry, cold air masses from the northeast (Bednorz 2002, Nowosad 2005).

In the analysed multiannual period, the North Atlantic Oscillation has a statistically significant impact on thermal conditions in December. The correlation was positive, so the negative stage of NAO was accompanied with a drop in air temperature, and the positive stage saw a rise. The strongest relation between NAO and air temperature was recorded in south-western and north-eastern Poland, while the weakest was in south-eastern Poland. The value of the correlation coefficient ranged from 0.55 in Rzeszów to 0.65 in Wrocław and Zielona Góra. As the above-mentioned data show, NAO explains $>40 \%$ of air temperature variance in the south-western part of the analysed area, and approximately $30 \%$ in the south-eastern part. In the analysed 49 years, the NAO index in December varied from -1.88 (2009) to 2.25 (2011) (Fig. 4). The value of the NAO index during the coldest December (1969) was -0.35 , while during the warmest (2006) it was 1.15. In the analysed period no statistically significant changes in the NAO index were observed.

\section{Thermal conditions during the Christmas period}

The mean Christmas-period temperature within the analysed multiannual period was $-0.4^{\circ} \mathrm{C}$. On average, the coldest Christmas was

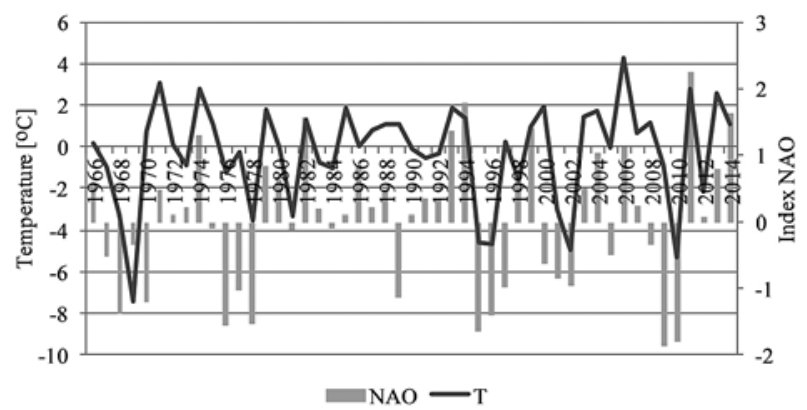

Fig. 4. Mean air temperature $\left({ }^{\circ} \mathrm{C}\right)$ in December in Poland between 1966 and 2014, and monthly value of the NAO index.

recorded in 2002, when the mean temperature fluctuated between $-15.4^{\circ} \mathrm{C}$ in Warszawa and $-5.1^{\circ} \mathrm{C}$ in Świnoujście. Temperatures below $-15^{\circ} \mathrm{C}$ also occurred at Christmas time in Suwałki and Białystok (Fig. 5). In four stations (Białystok, Gorzów Wielkopolski, Suwałki and Zielona Góra), the coldest Christmas was recorded in 1996, and the lowest air temperature was found in Suwałki $\left(-17 \cdot 4^{\circ} \mathrm{C}\right)$. On the other hand, the warmest Christmas occurred in 2013, when the mean air temperature fluctuated between $3.7^{\circ} \mathrm{C}$ in Białystok and $8.1^{\circ} \mathrm{C}$ in Wrocław. Except for the stations located in south-eastern Poland (Kraków, Lublin, Rzeszów), a slight increase in air temperature was observed in the analysed multiannual period, although the changes were not statistically significant. The last several Christmas seasons have been characterised by a much higher air temperature than the average temperature in the analysed multiannual period; 2013 in particular stood out. Within the analysed period, the range of air temperature deviation in a particular year from the multiannual period's mean value fluctuated from $-14.7^{\circ} \mathrm{C}$ (Suwałki, 1996; Warszawa, 2002) to $8.6^{\circ} \mathrm{C}$ (Kraków, 1983).

\section{The impact of atmospheric circulation on thermal conditions}

In the Euro-Atlantic sector in December between 1966 and 2014, the mean sea level pressure reached the highest values in the region of the Azores (>1020 hPa) (Fig. 6). The pressure drop occurred in a northerly direction, and the low pressure centre was located in the southwest of Iceland $(<999 \mathrm{hPa})$. A considerable horizontal pressure gradient was observed between the mentioned pressure centres over the ocean, but it 
Kraków

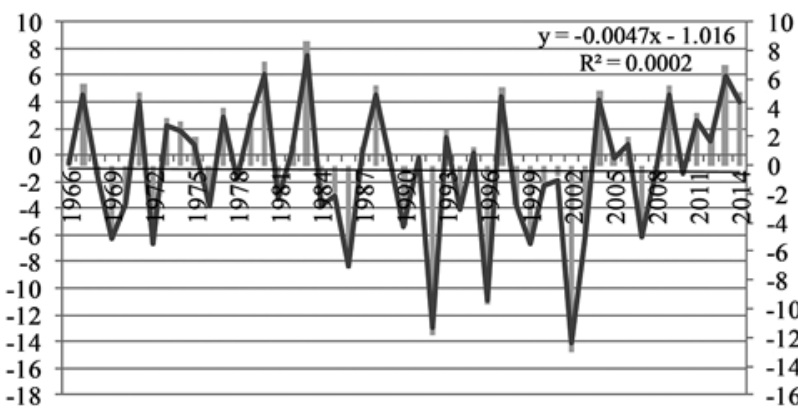

Warszawa

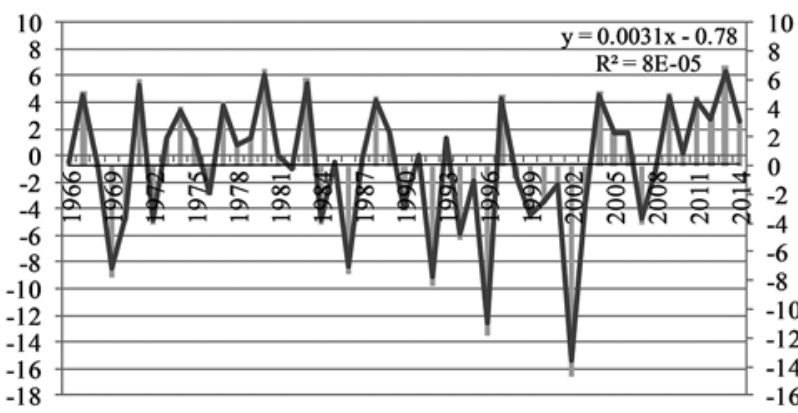

Suwalki

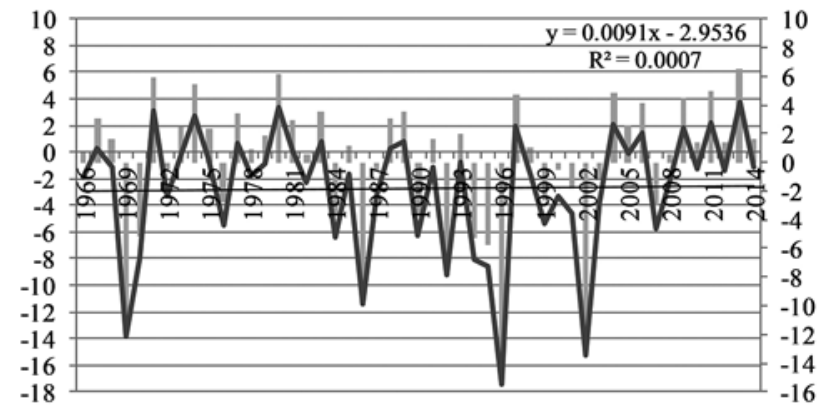

Wroclaw

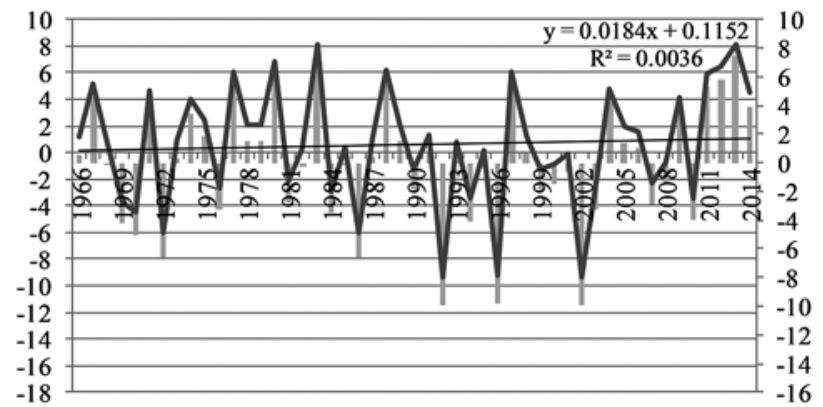

Fig. 5. Mean air temperature $\left({ }^{\circ} \mathrm{C}\right)\left(\right.$ line) in the Christmas period and air temperature anomalies $\left({ }^{\circ} \mathrm{C}\right)$ from the mean air temperature in 1966-2014 Christmas period (columns) in selected stations.

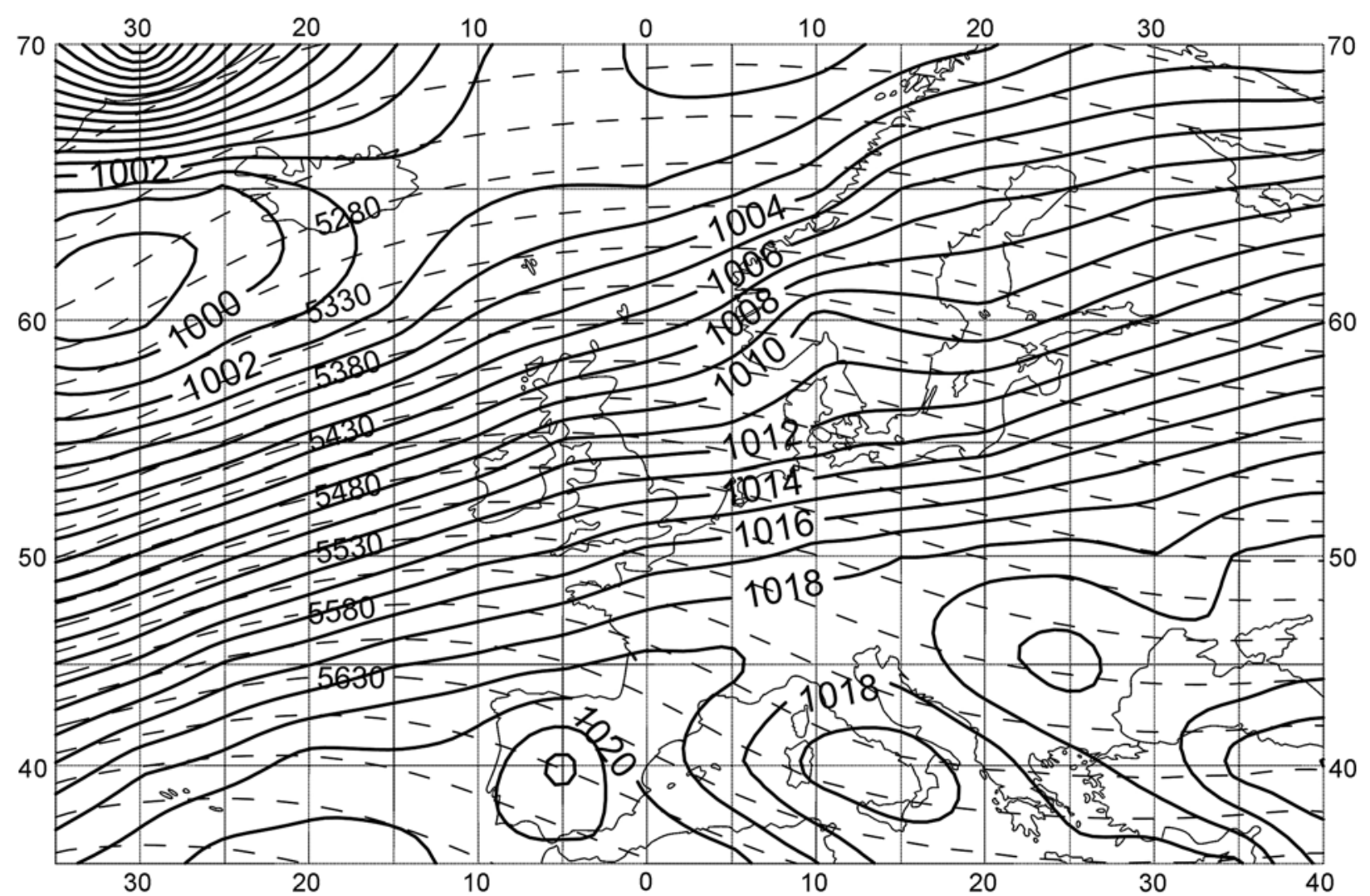

Fig. 6. Mean SLP (in hPa) and z500 hPa (in gpm) in December between 1966 and 2014. 

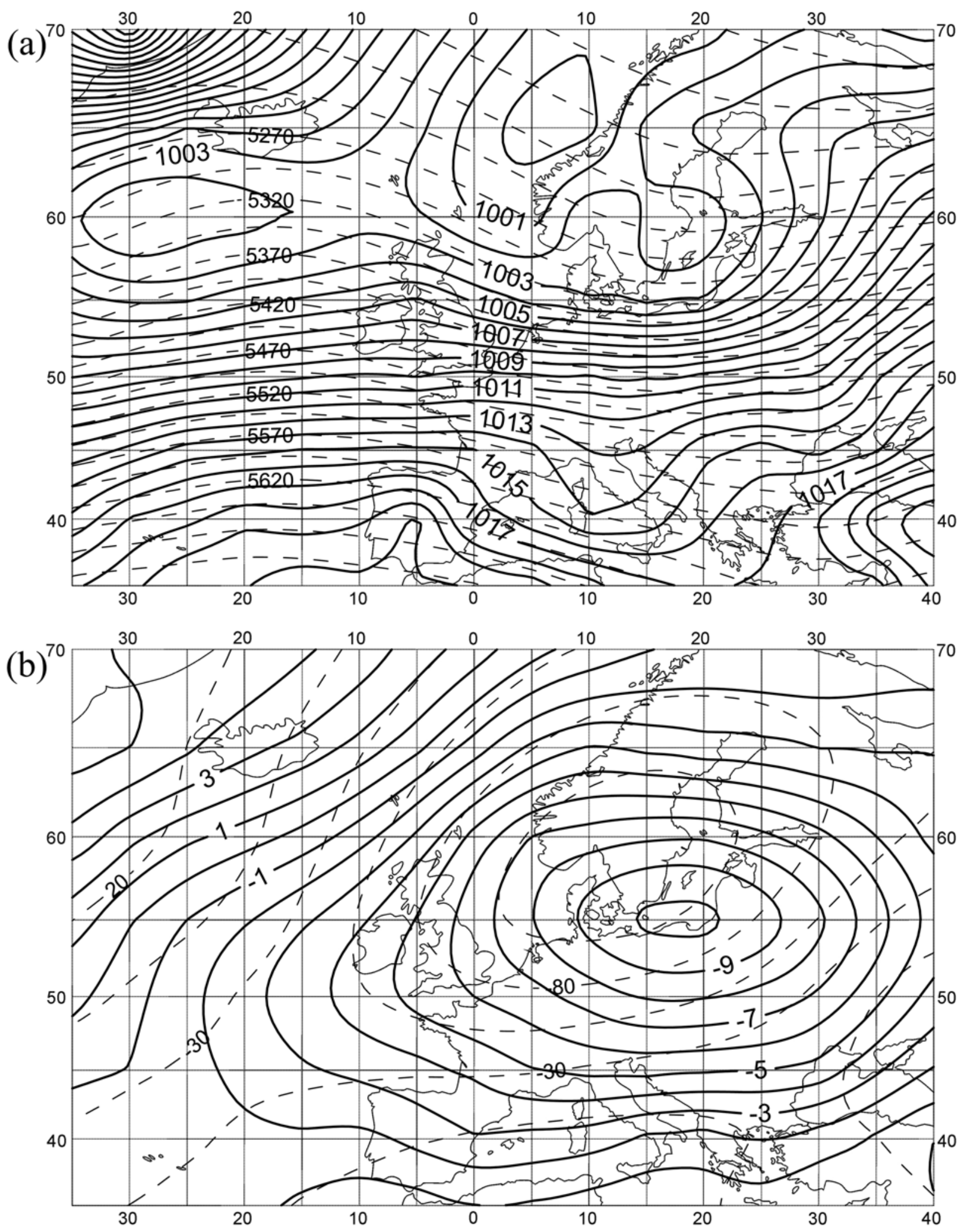

Fig. 7. Mean SLP (in hPa) and z500 hPa (in gpm) during the Christmas period (a) and SLP (in hPa) and z500 $\mathrm{hPa}$ (in gpm) anomalies (b) in type 1. 

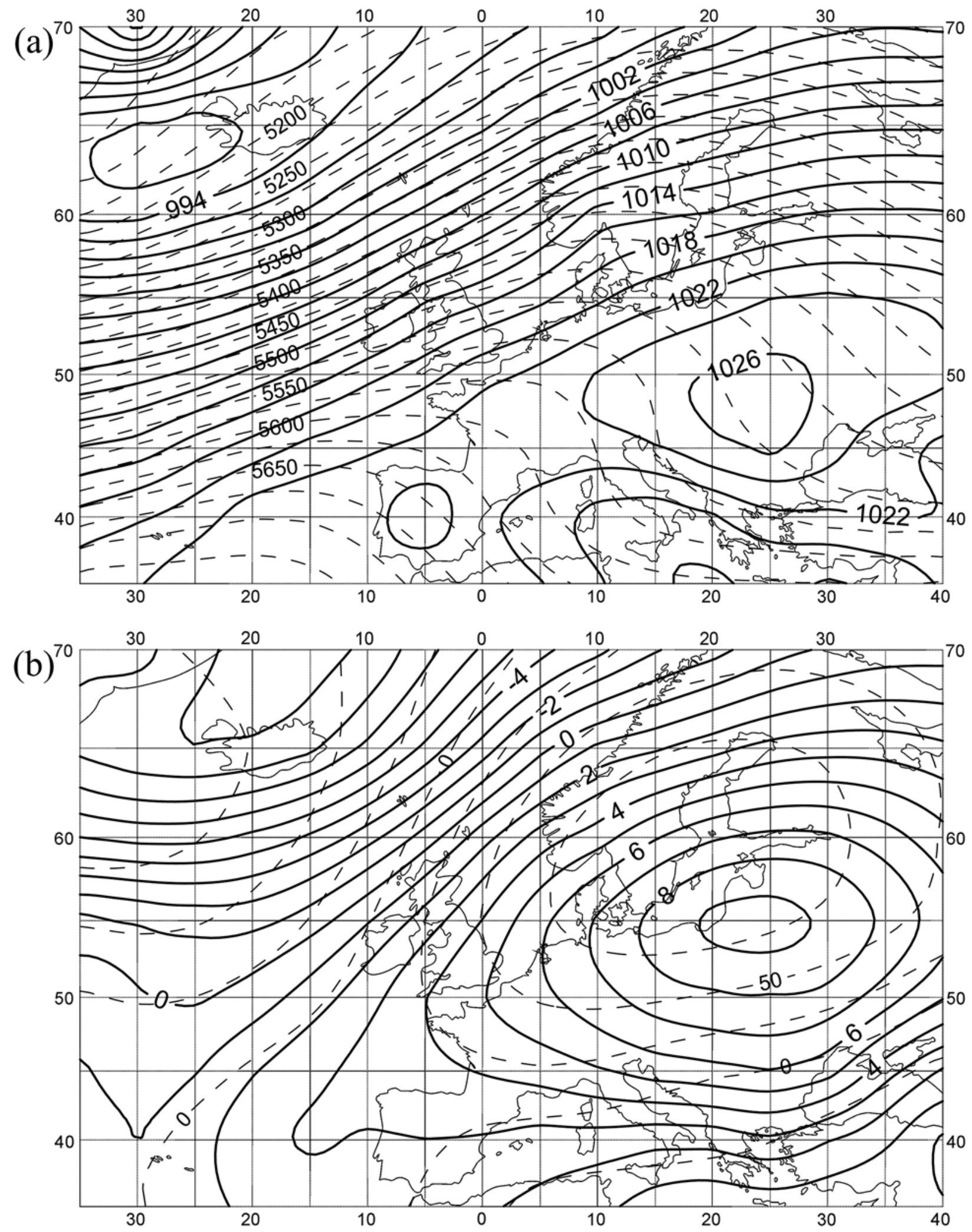

Fig. 8. Mean SLP (in hPa) and z500 hPa (in gpm) during the Christmas period (a) and SLP (in hPa) and z500 $\mathrm{hPa}$ (in gpm) anomalies (b) in type 2. 
was far less considerable over the continent. The averaged $500 \mathrm{hPa}$ isobaric surface was inclined towards the north. The maximum height was recorded over the Azores ( $>5700 \mathrm{gpm})$, while the minimum was observed over the North Atlantic $(<5200 \mathrm{gpm})$. Changes in the height of $500 \mathrm{hPa}$ isobaric surface show a change in air temperature of air masses. This is connected with the relationship between air temperature and density and the resulting pressure change with height in different thermal conditions: cool air masses are higher in density than warm masses, and therefore the drop in pressure as one ascends is quicker.

The pressure conditions occurring during Christmas were grouped into two types. 26 Christmas seasons were categorized as Type 1, and their mean air temperature was $1.3^{\circ} \mathrm{C}$. This type included, among others, the two warmest seasons; that is, those of $2013\left(6.0^{\circ} \mathrm{C}\right)$ and 1980 $\left(5.5^{\circ} \mathrm{C}\right)$. On the analysed days, sea level pressure over Poland varied between 1003 and $1010 \mathrm{hPa}$, and was lower than the winter average by approximately $8 \mathrm{hPa}$ in the south of Poland to $>10$ $\mathrm{hPa}$ in the north, where the centre of anomalies was located (Fig. 7). Between the areas of lower pressure in the north of Europe and high pressure in the south, a great horizontal pressure gradient stretched latitudinally. This system caused a strong inflow of maritime polar warm air masses over the Atlantic. The contour lines of the isobaric surface $500 \mathrm{hPa}$ over Central Europe bent southward, which may suggest the inflow of cool air masses from the northwest in the upper layers of the atmosphere. The $\mathrm{z} 500 \mathrm{hPa}$ anomalies ran similarly to SLP anomalies, with a slight shift towards the northwest.

Type 2 included 23 Christmas seasons whose mean temperature was $-2.4^{\circ} \mathrm{C}$. In this type are found, among others, the two coldest seasons, that is the Christmas of $2002\left(-11.5^{\circ} \mathrm{C}\right)$ and 1996 $\left(-10.1^{\circ} \mathrm{C}\right)$. During the mentioned seasons, Poland was averagely located within the reach of a high with its centre over Ukraine $(>1026 \mathrm{hPa}$ at its centre) (Fig. 8). The whole continent stayed within SLP positive anomalies centred over Poland and Kaliningrad Oblast $(>9 \mathrm{hPa})$. The described pressure system (depending on the exact location of the high) caused the inflow of dry and frosty continental air masses from the eastern sector. Additionally, cloudlessness or little cloud cover during high-pressure weather was conducive to strong heat emission from the surface at night. The contour lines of the $500 \mathrm{hPa}$ isobaric surface bent northward, which may indicate the inflow of warm air masses from the west (or even southwest) in the upper layers of the atmosphere.

\section{Discussion and summary}

In Poland in the analysed multiannual period, an increase in December air temperatures was observed, although the changes are not statistically significant. Similarly, a lack of statistically significant changes in air temperature in December between 1951 and 2010 was shown by Wójcik and Miętus (2014). At the time, the authors emphasized that the speed and direction of changes of air temperature in winter are strongly dependent on the period being analysed. Among the 49 years analysed in this study, the lowest mean air temperature in December was recorded in 1969. The above-mentioned month was classified as an anomalously cold month in, among others, Lublin (Filipiuk 2011) and Koszalin (Kirschenstein 2013). What is more, the December of 2010 clearly stood out against the multiannual period with, on average, an air temperature $5.1^{\circ} \mathrm{C}$ lower than the multiannual mean. That month was recognized in, among others, Great Britain, as the coldest December in over 100 years (Eden 2011, Moore and Renfrew 2012). One distinctive feature of the course of air temperature throughout the month was the occurrence of warming during the Christmas period. In the literature, this short warming is termed the Christmas thaw' (Fortuniak et al. 1998, Dubicki et al. 2002).

In the analysed multiannual period, in the majority of Poland, an increase in air temperature was recorded during the Christmas period, although these changes were not statistically significant. The coldest Christmas was recorded in 2002 and 1996, while the warmest was in 2013. In recent years, the occurrence of Christmases with higher-than-mean air temperatures for those days in the multiannual period has been confirmed. The occurrence of warmer Christmas was connected with the presence of low pressure systems over northern Europe causing the inflow of warmer maritime polar air masses over the Atlantic. Similar pressure systems were indicated by Bednorz (2012), who analysed synoptic 
situations conducive to the intensive melting of snow cover. On the other hand, colder Christmas periods were associated with an anticyclonic system bringing frosty continental air masses from the eastern sector. Anticyclonic systems located over Central or Eastern Europe are also conducive to extending the time of snow retention (Bednorz 2011). As Ustrnul et al. (2010) showed, high pressure situations with air inflow from the eastern sector are of predominant significance to the occurrence of temperature minima.

\section{References}

Bardin M.Yu., 2011. Scenary Forecasts of Air Temperature Variations for the Regions of the Russian Federation up to 2030 Using the Empirical Stochastic Climate Model. Russian Meteorology and Hydrology 36 (4): 217-228.

Bartolini G., di Stefano V., Maracchi G., Orlandini S., 2012. Mediterranean warming is especially due to summer season. Theoretical and Applied Climatology 107 (1-2): 279-295.

Bednorz E., 2002. Snow cover in western Poland and macro-scale circulation conditions. International Journal of Climatology 22: 533-541.

Bednorz E., 2006. A white Christmas or a Christmas thaw? - changes in snow cover depth in German - Polish lowlands during the last decade of December against daily circulation patterns. Meteorologische Zeitschrift 15: 1-5.

Bednorz E., 2011. Synoptic conditions of snow cover occurrence in central European lowlands. International Journal of Climatology 31: 1108-1118.

Bednorz E., 2012. Atmospheric conditions of intense thaws in the Polish lowlands. Meteorologische Zeitschrift 21 (1): 89-98.

Bielec-Bąkowska Z., 2010. Strong highs over Europe in 20th century. In: L. Kolendowicz (ed.), Klimat Polski na tle klimatu Europy, Warunki cyrkulacyjne $i$ radiacyjne, Poznań: 23-37 (in Polish).

Birkeland K.W., Mock C.J., 1996. Atmospheric circulation patterns associated with heavy snowfall events, Bridger Bowl, Montana, U.S.A. Mountain Research and Development 16: 281-286.

Brázdil M., Budíková M., Auer I., Böhm R., Cegnar T., Faško P., Lapin M., Gajić-Čapka M., Zaninović K., Koleva E., Niedźwiedź T., Ustrnul Z., Szalai S., Weber R.O., 1996. Trends in maximum and minimum daily temperatures in Central and Southeastern Europe. International Journal of Climatology 16: 765-782.

Degirmendžić J., Kożuchowski K., Żmudzka E., 2004. Changes of air temperature and precipitation in Poland in the period 1951-2000 and their relationship to atmospheric circulation. International Journal of Climatology 24: 291-310.

Dubicki A., Dubicka M., Szymanowski M., 2002. The climate of Wrocław. In: Środowisko Wrocławia - Informator 2002, Dolnośląska Fundacja Ekorozwoju, 9-25 (in Polish).

Eden P., 2010. December 2010, Coldest December since 1890. Weather 66 (4): II-V.

Esteban P., Jones P.D., Martin-Vide J., Mases M., 2005. Atmospheric circulation patterns related to heavy snowfall days in Andorra, Pyrenees. International Journal of Climatology 25: 319-329.

Filipiuk E., 2011. Thermal classification of months, seasons and years in Lublin (1951-2010). Prace i Studia Geograficzne 47: 129-138 (in Polish).

Fortuniak K., Kożuchowski K., Papiernik Ż., 1998. The annual thermical rhythm of Poland's climate and its seasonal singularities. Przeglad Geofizyczny LXX (3-4): 283-304 (in Polish).

Fortuniak K., Kożuchowski K., Żmudzka E., 2001. Trends and periodicity of changes in air temperature in Poland in the second half of 20 the century. Przeglad Geofizyczny XLVI (4): 283-303 (in Polish).

IPCC 2013. Climate change: The physical science basis. Contribution of Working Group I to the Fifth Assessment Report of the Intergovernmental Panel in Climate Change, Cambridge University Press, Cambridge.

Kalnay E., Kanamistu M., Kistler R., Collins W., Deaven D., Gandin L., Iredell M., Saha S., White G., Woollen J., Zhu Y., Leetmaa A., Reynolds R., Chelliah M., Ebisuzaki W., Higgins W., Janowiak J., Mo K.C., Ropelewski C., Wang J., Jenne R., Joseph D., 1996. The NMC/NCAR 40-Year Reanalysis Project. Bulletin of the American Meteorological Society 77: 437-471.

Kirschenstein M., 2013. The characteristics of temperature changes in Koszalin in winter season from 1850 to 2010 and their relation to North Atlantic Oscillation. Baltic Coastal Zone 17: 35-52.

Klein Tank A.M.G., Können G.P., 2003. Trends in indices of daily temperature and precipitation extremes in Europe, 1946-99. Journal of Climate 16: 3665-3680.

Kożuchowski K., Żmudzka E., 2001. The warming in Poland: the range and seasonality of the changes in air temperature in the second half of 20th century. Przeglad Geofizyczny 46 (1-2): 81-90 (in Polish).

Kürbis K., Mudelsee M., Tetzlaff G., Brázdil R., 2009. Trends in extremes of temperature, dew point, and precipitation from long instrumental series from Central Europe. Theoretical and Applied Climatology 98: 187-195.

Marsz A.A., 2013. Frequency of mid-tropospheric circulation macro-types following Wangengejm-Girs classification during winter period and the atmospheric pressure field over Europe and North Asia. Przeglad Geofizyczny 1-2: 3-24 (in Polish).

Michalska B., 2011. Tendencies of air temperature changes in Poland. Prace i Studia Geograficzne 47: 67-75 (in Polish).

Moore G.W.K., Renfrew I.A., 2012. Cold European winters: Interplay between the NAO and the East Atlantic mode. Atmospheric Science Letters 13, 1-8.

Nordli Ø., Przybylak R., Ogilvie A.E.J., Isaksen K., 2014. Long-term temperature trends and variability on Spitsbergen: the extended Svalbard Airport temperature series, 1898-2012. Polar Research 33, 21349, http://dx.doi. org/10.3402/polar.v33.21349.

Nowosad M., 2005. Again on history of research of the North Atlantic Oscillation. Wiadomości Meteorologii, Hydrologii, Gospodarki Wodnej 1: 81-88 (in Polish).

Porębska M., Zdune M., 2013. Analysis of extreme temperature events in Central Europe related to high pressure blocking situations in 2001-2011. Meteorologische Zeitschrift 22 (5): 533-540.

Rydén J., 2015. Is a White Christmas becoming rarer in southern parts of Sweden? Theoretical and Applied Climatology 121: 53-59. 
Ustrnul Z., Czekierda D., Wypych A., 2010. Extreme values of air temperature in Poland according to different atmospheric circulation classifications. Physics and Chemistry of the Earth 35: 429-436.

Ward J.H., 1963. Hierarchical grouping to optimize an objective function. Journal of the American Statistical Association 58: 236-244.
Wibig J., Głowicki B., 2002. Trends of minimum and maximum temperature in Poland. Climate Research 20: 123-133.

Wójcik R., Miętus M., 2014. Some features of long-term variability in air temperature in Poland (1951-2010). Przeglad Geograficzny 86 (3): 339-364 (in Polish). 